\title{
Media Coverage of Injury Prevalence in Tennis: a Content Analysis of Selected Online Newspapers
}

\author{
Isyaku Hassan ${ }^{1}$, Rabiu Muazu Musa, Mohd Nazri Latiff Azmi, \\ Mohamad Razali Abdullah, Ahmad Taufik Hidayah Abdullah
}

Universiti Sultan Zainal Abidin. Terengganu, Malaysia

\begin{abstract}
The health benefits of tennis have been well-described. However, like many other sports, playing tennis places athletes at risk of injury with a lot of physical and psychological effects. Thus, research has indicated the need for systematic studies to design useful strategies for the prevention and treatment of tennis-related injuries. Therefore, via a media-based analysis, this study aims to identify the most commonly reported tennis-related injuries and determine the extent of their news coverage in selected Nigerian online newspapers. Vanguard, Punch, The Nation, The Sun, and ThisDay were selected based on their popularity and online readership. A total of 113 tennis-related news articles were gathered via an internet-based search and subjected to content analysis. The articles were collected from January 2015 until December 2020 using "tennis" and "injury" as keywords. The findings showed that tennis-related injuries occur more often in lower extremities than upper extremities. Also, knee injury, hip injury, and elbow injury were the most commonly reported tennis-related injuries in the selected newspapers. Interestingly, these findings concur with previous clinical research on tennis-related injuries. Further analysis revealed that the selected newspapers paid much attention to tennis-related injuries. However, very few news stories reported official responses to tennis injuries. It was envisaged that this study could provide valuable insights on how to discover more efficient data for tennis injury analysis.
\end{abstract}

\section{Keywords}

Agenda-Setting; Injury; Newspaper; News Content; Tennis; News Coverage; Sports; Injury Data; Tournament

This work is licensed under a Creative Commons «Attribution» 4.0 International License

1 Corresponding author. Email: isyaku87[at]gmail.com 


\section{Отражение в СМИ случаев травматизма в теннисе: контент анализ отдельных интернет-газет}

\section{Хасан Исяку ${ }^{1}$ Муса Рабиу Муазу, Азми Мохд Назри Латифф, Абдулла Мохамад Разали, Абдулла Ахмад Тауфик Хидайя}

Университет им. Султана Зайнала Абидина. Тренгану, Малайзия

\section{Аннотация}

Польза тенниса для здоровья хорошо описана. Однако, как и многие другие виды спорта, игра в теннис подвергает спортсменов риску травм с множеством физических и психологических последствий. Таким образом, проведённые изыскания указывают на необходимость систематических исследований для разработки эффективных стратегий профилактики и лечения травм, связанных с игрой в теннис. Поэтому, используя анализ СМИ, данное исследование направлено на выявление наиболее часто сообщаемых травм, связанных с теннисом, и определение степени их освещения в отдельных нигерийских интернет-газетах. Газеты Vanguard, Punch, The Nation, The Sun и This-Day были выбраны на основании их популярности и онлайновой читательской аудитории. Всего 113 новостных статей, связанных с теннисом, были собраны с помощью поисковых запросов в Интернете и подвергнуты контент-анализу. Статьи были отобраны с января 2015 года по декабрь 2020 года с использованием ключевых слов "теннис" и "травма". Результаты показали, что травмы, связанные с теннисом, чаще наблюдались на нижних конечностях, чем на верхних. Кроме того, травмы колена, бедра и локтя были самыми распространёнными травмами, связанными с теннисом, о которых сообщалось в отобранных газетах. Интересно, что эти результаты совпадают с предыдущими клиническими исследованиями травм, связанных с теннисом. Дальнейший анализ показал, что выбранные газеты уделяли много внимания травмам, связанным с теннисом. Однако в очень небольшом количестве новостей сообщалось об официальных мерах реагирования на теннисные травмы. Предполагается, что данное исследование может дать ценные идеи о том, как получить более эффективные данные для анализа травм в теннисе.

\section{Ключевые слова}

установление повестки дня; травма; газета; содержание новостей; теннис; освещение новостей; спорт; данные о травмах; соревнования

Это произведение доступно по лицензии Creative Commons «Attribution» («Атрибуция») 4.0 Всемирная

1 Корреспондирующий автор. Email: isyaku87[at]gmail.com 


\section{Introduction}

Tennis is one of the most popular sports worldwide (Dines, Bedi, Williams, Dodson, Ellenbecker, Altchek, \& Dines, 2015; Kovacs, 2006; Pluim \& Windler, 2018) with participation in over 200 countries (ITF, 2021) and more than one billion active fans (Buzz Nigeria, 2018). Millions of dollars are spent on tennis prizes at different levels of tournaments (Pluim, Staal, Windler, \& Jayanthi, 2006; Pluim \& Windler, 2018). The health benefits of tennis have been well-described (Pluim, Staal, Marks, Miller, \& Miley, 2007; Pluim, Groppel, Miley, Crespo, \& Turner, 2018). However, injuries often occur in tennis despite being a noncontact sport (Pluim \& Windler, 2018). An injury is simply defined as a complaint by players seeking medical attention or receiving treatment (Correia, 2016; Pluim, Fuller, Batt, Chase, Hainline, Miller, ... \& Wood, 2009).

Like other sports, playing tennis places players at risk of injury (Fu, Ellenbecker, Renstrom, Windler, \& Dines, 2018; Pluim et al., 2006; Pluim \& Safran, 2004). Sports injuries often cause disability or absence from work (Dekker, Groothoff, Van Der Sluis, Eisma, \& Ten Duis, 2003), which can result in significant socioeconomic concerns (Pluim et al., 2006). Therefore, research indicates the need for systematic studies to better understand tennis-related injuries and design useful strategies to prevent the occurrence of such injuries (Fu et al., 2018; Kaiser, Stock, Benedikt, Ellenbecker, Kastenberger, Schmidle, \& Arora, 2021; Pluim et al., 2006). However, the collection of accurate data for tennis injury analysis remains a challenge (Pluim, Loeffen, Clarsen, Bahr, \& Verhagen, 2016).

Additionally, robust methods of injury data collection are required to allow a sophisticated analysis of tennis-related injuries (McCurdie, Smith, \& Batt, 2017). In this regard, research has shown the importance of mainstream media, particularly newspapers, in providing useful data for injury analysis (Ghaffar, Hyder, \& Bishai, 2001; Musa, Hassan, Abdullah, Azmi, \& Mat-Rasid, 2019). According to Ghaffar et al. (2001), newspapers cover more injury-related events than other sources. When an injury occurs, such an incident is likely to become newsworthy events and topics of interest amongst the audiences. As such, newspapers serve as a potential source of injury data (Berchialla, Scarinzi, Snidero, Rahim, \& Gregori, 2012; Hassan, Musa, Azmi, Abdullah, \& Abdullah, 2020).

Previous studies analyzed tennis-related injuries using different designs (Maquirriain \& Baglione, 2016; Pluim et al., 2016; Kaiser et al., 2021). However, none of these studies focused on a media-based analysis of tennis-related injuries. Also, there is a paucity of injury data analysis in developing countries (Azubuike \& Okojie, 2009; Ghaffar et al., 2001). Therefore, via news content analysis, this study explores news coverage of tennis-related injuries in selected Nigerian online newspapers from January 2015 until December 2020. Vanguard, Punch, The Nation, The Sun, and ThisDay were selected based on their online readership and popularity. To the best of our knowledge, this study is an initial attempt to investigate injury prevalence 
in tennis from the mainstream media perspective. Specifically, this study aims to address the following research questions.

1. What are the most commonly reported tennis-related injuries in the selected online newspapers?

2. To what extent do the newspapers cover tennis-related injuries within the chosen period?

\section{Injury Prevalence in Tennis}

Several studies were conducted to investigate tennis-related injuries with different designs and populations (e.g. Gescheit, Cormack, Duffield, Kovalchik, Wood, Omizzolo, \& Reid, 2017; Hjelm, Werner, and Renstrom, 2010; Kaiser et al., 2021; Kovacs, Ellenbecker, Kibler, Roetert, \& Lubbers, 2014; Kühne, Zettl, \& NastKolb, 2004; Lynall, Kerr, Djoko, Pluim, Hainline, \& Dompier, 2015; Maquirriain \& Baglione, 2016; Pluim et al., 2016; Sell, Hainline, Yorio, and Kovacs, 2014). Most of these studies reported that tennis-related injuries occurred in the lower extremity, followed by the upper extremity and the trunk (e.g. Kaiser et al., 2021; Kühne et al., 2004; Lynall et al., 2015; Maquirriain \& Baglione, 2016; Pluim et al., 2006; Pluim et al., 2016; Pluim \& Windler, 2018; Sell et al., 2014).

A recent retrospective study investigated a total of 467 acute injuries in tennis (Kaiser et al., 2021). According to the findings, most injuries occurred in the lower extremity, followed by the upper extremity, head, and trunk. Sell et al. (2014) also found that tennis-related "injuries to the lower limbs were over three times more likely than injuries to the trunk" (p. 4). Similarly, a recent retrospective study investigated a total of 467 acute injuries in tennis (Kaiser et al., 2021). According to the findings, most injuries occurred in the lower extremity, followed by the upper extremity, head, and trunk. In essence, previous studies showed that in tennis, lower extremities are more susceptible to injuries. This susceptibility has been attributed to the overuse of lower limb injuries (Pluim et al., 2009).

Additionally, previous studies showed that most acute tennis injuries occur in the lower extremity, while chronic injuries occur in the upper extremity (e.g. Dines et al., 2015; Fu et al., 2018; Kühne et al., 2004; Pluim \& Windler, 2018; Verhagen, Clarsen, Capel-Davies, Collins, Derman, de Winter,... \& Pluim, 2021). Specifically, the most affected locations include the knee, ankle, shoulder, wrist, back, foot, hip, and low back pain (Ellenbecker, Pluim, Vivier, \& Sniteman, 2009; Fu et al., 2018; Hjelm et al., 2021; Kaiser et al., 2021; Kovacs et al., 2014; Pluim \& Windler, 2018; Sell et al., 2014). According to Pluim and Windler (2018), the knee is a frequently injured joint in tennis because the location "is typically related to repetitive eccentric overload" (p. 46).

The previous studies have focused on injury analysis at different levels of tennis, including elite professional tennis (Gescheit et al, 2017; Maquirriain \& Baglione, 2016; McCurdie et al., 2017; Sell et al., 2014) and junior tennis (Hjelm et al., 
2010; Kovacs et al., 2014; Pluim et al., 2016). Although tennis-related injuries have been reported throughout body regions (Ellenbecker et al., 2009), some studies highlighted that elite professional tennis is more injurious compared with other categories of tennis (Gescheit et al., 2017; Maquirriain \& Baglione, 2016). Therefore, more research is needed at all levels of tennis to help health professionals develop injury prevention strategies (Flu et al., 2018).

Moreover, previous studies analyzed tennis-related injuries using different designs such as epidemiological research (e.g. Lynall et al., 2015; Maquirriain \& Baglione, 2016), prospective research (e.g. Hjelm et al., 2010; Pluim et al., 2016), and retrospective research (e.g. Kaiser et al., 2021; Kühne et al., 2004). A review of tennis-related injury data "showed relatively consistent results since 2013" (Pluim \& Windler, 2018, p. 48). However, tennis injury prevalence may vary depending on data sources and classification systems. None of the previous studies focused on a media-based analysis of tennis-related injuries. To the best of our knowledge, this study is the first attempt to investigate injury prevalence in tennis from the mainstream media perspective. The media can provide health professionals and relevant authorities with valuable injury data to develop preventive measures, rehabilitation programs, and effective post-injury interventions (Hassan et al., 2020; Musa et al., 2019; Sell et al., 2014).

\section{Theoretical Approach}

This study adopts Agenda-setting theory to explain how Nigerian newspapers cover tennis-related injuries. The development of this theory is attributed to McCombs and Shaw (1972) who provided the first robust support for the agendasetting effect. Their study showed that the media tend to make certain issues more salient than others and offer clues about the salient issues in the daily news. By restating these clues day after day, the media successfully communicate the prominence of each issue. Thus, the analysis revealed that how much importance is attached to an issue depends on its salience in the news. As such, the power of media to influence public agenda by focusing on the salience of particular issues is a well-documented phenomenon (Okwuchukwu, 2014; Potter, 2012).

Agenda-setting focuses on the media's ability to provide salience to particular topics while de-emphasizing others in news dissemination (Lim, 2010). Therefore, there is a connection between what the media consider important and its salience in the audience's mindsets. Agenda-setting consists of two levels. The first-level of agenda-setting refers to the media's transfer of salient issues to society, while the second level refers to various elements competing for attention (McCombs \& Shaw, 1972; McCombs \& Shaw, 1993). This level is described as a process of presenting specific issues frequently and prominently, where large segments of society come to perceive such issues as more serious than others (Coleman, McCombs, Shaw, \& Weaver, 2009). In this case, the extent of news coverage of 
particular issues, such as tennis-related injuries, determines the perceived importance of those issues in the audience's mindsets.

The second-level of agenda-setting expands the original meaning of agendasetting. This level focuses on the attributes and characteristics of a particular issue as well as its tone of coverage. In this case, agenda-setting tends to define how people think about the subject, individual, or group being reported. The attributes of second-level agenda-setting consist of two dimensions: substantive and affective dimensions. The substantive dimension is concerned with certain attributes such as ideology and personality of the subject being reported, whereas the affective dimension focuses on the emotional qualities of those attributes where the tone of news reports become positive, negative, or neutral tone (Kim \& McCombs, 2007; McCombs \& Shaw, 1993).

Additionally, some of the elements associated with agenda-setting include the frequency or extent of news coverage and level of prominence (Folarin, 1998) as well as news sources (Berkowitz, 1992). These elements define issues and determine their future discourse. The media's ability to make certain issues salient in the audience's mindsets depends on these elements. Based on this argument, this study explores the characteristics and prominence accorded to tennis-related injuries in selected Nigerian online newspapers.

\section{Methodology}

\section{Design}

This study adopts content analysis to investigate the news coverage of tennisrelated injuries in five major Nigerian newspapers. Content analysis was chosen due to its ability to explore the characteristics of media messages. This because content analysis provides specific media content that can be analyzed to produce useful information. This method also looks at communication via texts and allows for both quantitative and qualitative analyses (Oleinik, 2011; Shannon, 2005). Content analysis is recognized as a research method based on facts, as opposed to other methods such as discourse analysis (Weaver, 2007). According to Cohen, Manion, and Morrison (2007), "content analysis takes texts and analyses, reduces and interrogates them into summary form through the use of both pre-existing categories and emergent themes to generate or test a theory" (p. 476).

\section{Data Collection}

Five national newspapers with the highest readership and online popularity were selected for analysis: Vanguard, Punch, The Nation, The Sun, and ThisDay. These newspapers are the top daily English language publications in Nigeria (Top Ten Nigerian Newspapers, 2019). News articles focusing on tennis-related inquiries were collected from the respective digital archives of the selected newspapers between January 2015 and September 2020. This time represents a period with various tennis tournaments across the globe, such as Rio Tennis Olympics, 
Wimbledon Championships, Australian Open, and US Open. The time frame was chosen to make the data into a manageable size for analysis.

The news articles were collected using "Tennis" and "Injury" as keywords. All news articles identified using this method were included in the content analysis. Only straight news and feature stories were selected for analysis. A total of 113 relevant news articles were generated. Online news articles were considered in this study as readers can attend to online news at any time (Chung, 2008; Hassan \& Azmi, 2018). Newspapers are recognized as a more detailed and reliable source of data than traditional datasets (Berchialla et al., 2012; Ghaffar et al., 2001). Although data gathered from news content is considered qualitative, they can be computed to obtain quantifiable results. According to Hsieh and Shannon (2005), content analysis is mainly characterized as a qualitative versus quantitative research method.

\section{Data Analysis}

At the initial stage, each article in the original sample was read for relevance based on headlines and news content. The relevant content of each news article was studied and coded using a hierarchical code system. The hierarchical code system is advantageous as it represents a huge amount of information in a few digits (Hsieh \& Shannon, 2005). Subsequently, a database was generated with five categorical variables: Injury locations, extent of news coverage, tournaments, news sources, and official responses. To ensure consistency, inter-coder reliability was employed. The level of inter-coder agreement was determined using Cohen's kappa test. According to Berchialla et al. (2012), news content can provide valuable information on the prevalence and dimensions of unintentional injuries.

Moreover, the news articles were cross-checked to avoid double entry of data. Besides, the emerging themes were verified to avoid reproducing media content or revealing dominant themes containing certain tennis-related information. Specifically, the researchers aimed to explore tennis-related injuries and the extent of their coverage throughout the coding process. This method involves subjective judgment, but inter-coder reliability helps to achieve a systematic analysis (Creswell, 2003). The quantified data were analyzed using descriptive statistics and cross-tabulation procedures via the Statistical Package for Social Sciences (SPSS Inc., Chicago, Illinois, USA, 20.0).

\section{Findings}

The selected newspapers produced different amounts of articles related to tennis injuries within the chosen period of data collection. Punch published 34 news articles, Vanguard published 22 articles, The Sun published 13 articles, The Nation published 12 articles while ThisDay published 32 articles. Overall, 113 football-related articles were analyzed. News stories about tennis-related injuries are infrequent to allow the collection of a larger sample within the period of data 
collection. Nonetheless, newspapers are recognized as an accurate source of injury data (Ghaffar et al., 2001; Musa et al., 2019). The first question aims to identify the most commonly reported tennis-related injury locations in the selected newspapers. This information is depicted in Table 1 as follows.

\begin{tabular}{llccc}
\hline SN & Injury Locations & F/P & RF & CP \\
\hline 1 & Knee & $15(13.3)$ & 0.13 & 13.3 \\
2 & Hip & $14(12.4)$ & 0.12 & 25.7 \\
3 & Elbow & $12(10.6)$ & 0.11 & 36.3 \\
4 & Unidentified & $12(10.6)$ & 0.11 & 46.9 \\
5 & Shoulder & $10(8.8)$ & 0.09 & 55.7 \\
6 & Back & $9(8.0)$ & 0.08 & 63.7 \\
7 & Ankle & $8(7.1)$ & 0.07 & 70.8 \\
8 & Thigh & $6(5.3)$ & 0.10 & 76.1 \\
9 & Achilles & $5(4.4)$ & 0.04 & 80.5 \\
10 & Wrist & $5(4.4)$ & 0.04 & 84.9 \\
11 & Hamstring & $4(3.5)$ & 0.04 & 88.4 \\
12 & Arm & $3(2.7)$ & 0.03 & 91.1 \\
13 & Groin & $3(2.7)$ & 0.03 & 93.8 \\
14 & Foot & $2(1.8)$ & 0.02 & 95.6 \\
15 & Abdominal & $1(0.9)$ & 0.00 & 96.5 \\
16 & Glute & $1(0.9)$ & 0.00 & 97.4 \\
17 & Hand & $1(0.9)$ & 0.00 & 98.3 \\
18 & Leg & $1(0.9)$ & 0.00 & 99.2 \\
19 & Neck & $1(0.9)$ & 0.00 & 100.0 \\
\hline & Total & $\mathbf{1 1 3 ( 1 0 0 )}$ & $\mathbf{1 . 0 0}$ & \\
\hline & & & & 100.0 \\
\hline
\end{tabular}

Table 1: Reported tennis-related injuries

Note: $\mathrm{F} / \mathrm{P}=$ Frequency $/$ Percent, $\mathrm{RF}=$ Relative Frequency, $\mathrm{CP}=$ Cumulative Percent

As shown in Table 1, the selected newspapers reported 133 tennis-related injuries across 19 different injury locations. According to the findings, knee injury is the most commonly reported tennis-related injury $(13.3 \%)$ in the selected newspapers, followed by hip injury (12.4\%) and elbow injury (10.6\%). These locations amount to 41 injuries, representing $36.3 \%$ of the total number of reported injuries. The knee and hip are classified as lower limbs while the elbow belongs to the upper extremity. The findings indicate that tennis-related injuries occur more frequently in the lower extremity than the upper extremity. Besides, 12 injury locations, amounting to $10.6 \%$, were unidentified. 
Furthermore, the selected newspapers reported tennis-related injuries with various descriptions, such as career-threatening injury, dispiriting injury, freak injury, long-standing injury, recurring injury, and nagging injury. For instance, on October 1, 2020, ThisDay wrote, "McDonald, 25, suffered a career-threatening injury at last year's French Open." Also, injured players were described with several adjectives, such as injury-troubled and injury-plagued. For instance, on May 21, 2019, Vanguard reported that "Injury-troubled Osaka heads to French Open." Additionally, the extent of news coverage defines the level of importance accorded to the subject being reported" (Folarin, 1998). Thus, the second objective of this study was to determine the extent of news coverage of tennis-related injuries in the selected newspapers. This information is presented in Table 2 as follows.

\begin{tabular}{|c|c|c|c|c|c|}
\hline SN & Variables & Categories & $\mathrm{F} / \mathrm{P}$ & $\mathbf{R F}$ & $\mathbf{C P}$ \\
\hline \multirow[t]{5}{*}{1} & News Coverage & Global & $105(92.9)$ & 0.92 & 69.0 \\
\hline & & Regional & $4(3.5)$ & 0.04 & 55.8 \\
\hline & & Local & $2(1.8)$ & 0.02 & 33.6 \\
\hline & & National & $2(1.8)$ & 0.02 & 100.0 \\
\hline & & Total & $113(100)$ & 1.00 & 100.0 \\
\hline \multirow[t]{6}{*}{2} & Tournaments & Australian Open & $17(15.0)$ & 0.20 & 15.0 \\
\hline & & US Open & $16(14.2)$ & 0.14 & 29.2 \\
\hline & & French Open & $11(9.7)$ & 0.10 & 38.9 \\
\hline & & Unidentified & $11(9.7)$ & 0.10 & 48.6 \\
\hline & & Others & $58(51.3)$ & 0.51 & 100.0 \\
\hline & & Total & $113(100)$ & 1.00 & 100.0 \\
\hline \multirow[t]{7}{*}{3} & News Sources & News Agency & $47(41.6)$ & 0.42 & 41.6 \\
\hline & & Unidentified & $41(36.3)$ & 0.36 & 77.9 \\
\hline & & Other Media & $10(8.8)$ & 0.09 & 86.7 \\
\hline & & Correspondent & $9(8.0)$ & 0.08 & 94.7 \\
\hline & & Social Media & $5(4.4)$ & 0.04 & 99.1 \\
\hline & & Website & $1(0.9)$ & 0.01 & 100.0 \\
\hline & & Total & $113(100)$ & 1.00 & 100.0 \\
\hline \multirow[t]{3}{*}{4} & Official Responses & Reported & $25(22.1)$ & 0.22 & 22.1 \\
\hline & & Not reported & $88(77.9)$ & 0.78 & 100.0 \\
\hline & & Total & $113(100)$ & 1.00 & 100.0 \\
\hline
\end{tabular}

Table 2: Coverage of tennis-related injuries

Note: $\mathbf{F} / \mathbf{P}=$ Frequency $/$ Percent, $\mathbf{R F}=$ Relative Frequency, $\mathbf{C P}=$ Cumulative Percent

As shown in Table 2, the selected newspapers covered more global news (92.9\%) on tennis-related injuries than regional $(3.5 \%)$, local $(1.8 \%)$, or national 
(1.8\%). This outcome suggests that the selected newspapers accorded more prominence to global news on tennis-related injuries than regional, local, or national news. This is because, as postulated by Agenda-setting theory, the extent of news coverage defines the perceived prominence of the subject being reported (Coleman et al., 2009; Kim \& McCombs, 2007). Tennis events, especially international tournaments, represent a crucial aspect of sports activities. Table 2 also shows that the Australian Open, US Open, and French Open were the most frequently reported tennis events within the chosen period. These events were reported 44 times, which represents $38.9 \%$ of the total number of reported tournaments in the context of tennis-related injuries.

Additionally, most of the news stories about tennis injuries were reported from news agencies (41.6\%), followed by other mainstream media (8.8\%) and correspondent reports $(8.0 \%)$. Very few stories were reported from social media $(4.4 \%)$ and websites $(0.9 \%)$. This outcome shows that the selected newspapers relied on news agencies to report tennis-related injuries. Besides, 41 news sources, amounting to $36.3 \%$ of the overall news sources, were unidentified. Also, official responses to injuries were reported in only 25 incidents. This situation may affect the perceived credibility of tennis-related news. This is because useful injury-related information could be obtained from official responses such as sports medical personnel or tournament organizers.

\section{Discussion}

The findings of this study revealed that knee, hip, and elbow were the most commonly reported tennis-related injuries in the selected newspapers. According to the findings, lower limbs were more frequently affected compared with upper limbs. Interestingly, these findings concur with many prospective, retrospective, and epidemiological studies on tennis-related injuries (e.g. Kaiser et al., 2021; Kühne et al., 2004; Lynall et al., 2015; Maquirriain \& Baglione, 2016; Pluim et al., 2006; Pluim et al., 2016; Pluim \& Windler, 2018; Sell et al., 2014). Based on the supposition of Agenda-setting theory (McCombs \& Shaw, 1972), this outcome could provide the public, especially health professionals, tennis officials, and the players, with a signal about the most common injury locations in tennis through the transfer of salience.

Precisely, this study found that knee injury is the most commonly reported injury in the selected newspapers. According to Pluim and Windler (2018), knee injury is common as the location is subjected to repetitive unusual overload. Unlike other sports such as soccer, tennis involves running and skating, where loading mostly affects the lower extremities (Verhagen et al., 2021). Additionally, tennis does not have a specific predetermined duration, and therefore matches often last several hours with many shorts and bursts of energy (Dines et al., 2015; Kovacs, 2006). Despite this unique profile, many tennis-related injuries are common to other sports (Musa et al., 2019; Pluim \& Safran, 2004). 
Moreover, this study found that the selected newspapers reported more global news on tennis injuries than regional, local, or national news. These findings demonstrate the perceived importance accorded to tennis-related injuries in the selected newspapers. This is because, based on the assumption of AgendaSetting theory, the extent of news coverage is considered crucial in defining the level of prominence accorded to the subject being reported (Coleman et al., 2009; Folarin, 1998). Considering this assumption, tennis-related injuries receive tremendous media attention in Nigeria. However, the selected newspapers tend to rely on news agencies, such as Agence France-Presse (AFP), News Agency of Nigeria (NAN), and Reuters, as well as other conventional media, such as British Broadcasting Corporation (BBC) and Cable News Network (CNN, for information on tennisrelated injuries.

Further analysis revealed that very few news stories reported official responses to tennis-related injuries. To promote the richness of media-based information on tennis injuries, news sources must be diversified. This is because reporting sources define issues and determine their perceived accuracy (Berkowitz, 1992). The findings also suggest most tennis-related injuries were sustained during tournaments rather than training. Sports-related injuries often have physical and psychosocial impacts on athletes (Dekker et al., 2003), which may cause considerable socioeconomic concerns (Pluim et al., 2006). In particular, the Nigerian government spends a huge amount of money on the prevention and treatment of sportsrelated injuries (Azubuike \& Okojie, 2009). Therefore, studies of this nature are expected to supplement the government's efforts.

\section{Conclusion}

This study focused on the coverage of tennis-related injuries in selected Nigerian online newspapers. According to the findings, tennis injuries occur more frequently in lower limbs compared to upper limbs. Additionally, the selected newspapers accorded great prominence to tennis-related injuries. This prominence, as presumed based on Agenda-setting theory, can provide signals about the most common injury locations in tennis. The findings of this study signify the importance of media sources in analyzing tennis-related injuries. The study has proven that newspapers could be a robust alternative to prospective or clinical sources for tennis injury data. Accessibility, permanency, and timeliness make online newspapers a reliable source for tennis-related injuries.

This study advances our understanding of how newspapers can provide useful data for tennis injury analysis. To the best of our knowledge, this study is the first media-based analysis of tennis-related injuries. The findings of this research are expected to provide the government, health professionals, relevant authorities, and athletes with valuable insights on how to discover a more systematic approach to tennis injury prevention and management. This is because, through proper documentation and systematic analysis, studies of this nature could increase awareness 
and provide valuable information for tennis injury prevention, management, and rehabilitation programs.

This study is limited to tennis-related injuries in five Nigerian online newspapers with a small number of tennis-related injuries. News stories about tennis injuries were infrequent within the period of data collection (January 2015-December 2020). This situation restrains the collection of a relatively larger sample of news articles within the period of data collection. Therefore, further research may consider a larger sample of newspapers and a more extended period of data collection. Besides, only online newspapers were considered while other forms of media, such as blogs and social media, were viewed as too subjective for this study. Nevertheless, these forms of media could be useful alternative sources for data in future research.

\section{References / Список литературы}

Azubuike, S. O., \& Okojie, O. H. (2009). An epidemiological study of football (soccer) injuries in Benin City, Nigeria. British Journal of Sports Medicine, 43(5), 382-386. doi:10.1136/bjsm.2008.051565

Berchialla, P., Scarinzi, C., Snidero, S., Rahim, Y., \& Gregori, D. (2012). Information extraction approaches to unconventional data sources for "Injury Surveillance System": The case of newspapers clippings. Journal of Medical Systems, 36(2), 475-481. doi:10.1007/s10916-0109492-1

Berkowitz, D (1992). Who sets the media agenda? In Kennamer, J.D., (ed). The ability of policymakers to determine news decisions. Public opinion, the press, and public policy (pp. 91-134). Westport, CT: Praeger.

Buzz Nigeria (2018). Top ten world sports in massive fellowship. Retrieved from: https://buzznigeria.com/top-10-world-sports/

Chung, D. S. (2008). Interactive features of online newspapers: Identifying patterns and predicting use of engaged readers. Journal of Computer-Mediated Communication, 13(3), 658-679. doi:10.1111/ j.1083-6101.2008.00414.x

Cohen, L., Manion, L., \& Morrison, K. (2007). Research method in education. New York: Routledge.

Coleman, R., McCombs, M., Shaw, D., \& Weaver, D. (2009). Agenda setting. In K. Wahl-Jorgensen \& T. Hanitzsch (Eds.), The handbook of journalism studies (pp. 147-160). New York, NY: Routledge.

Correia, J. P. (2016). Injury surveillance at 23 International Tennis Federation Junior and Pro Circuit tournaments between 2011 and 2015. British Journal of Sports Medicine, 50(24), 1556-1556. doi: 10.1136/bjsports-2016-096255

Creswell, J. W. (2003). Research design: Qualitative, quantitative, and mixed methods approaches. London: Sage publications.

Dekker, R., Groothoff, J. W., Van Der Sluis, C. K., Eisma, W. H., \& Ten Duis, H. J. (2003). Long-term disabilities and handicaps following sports injuries: outcome after outpatient treatment. Disability and Rehabilitation, 25(20), 1153-1157. doi:10.1080/0963828031000137757 
Dines, J. S., Bedi, A., Williams, P. N., Dodson, C. C., Ellenbecker, T. S., Altchek, D. W., ... \& Dines, D. M. (2015). Tennis injuries: epidemiology, pathophysiology, and treatment. JAAOS-Journal of the American Academy of Orthopaedic Surgeons, 23(3), 181-189. doi:10.5435/JAAOS-D-13-00148

Ellenbecker, T. S., Pluim, B., Vivier, S., \& Sniteman, C. (2009). Common injuries in tennis players: exercises to address muscular imbalances and reduce injury risk. Strength $\mathcal{E}$ Conditioning Journal, 31(4), 50-58. doi:10.1519/SSC.0b013e3181af71cb

Folarin, B. (1998). Theories of mass communication: An introductory text. Ibadan: Stirling Horder Publishers.

French Open: Serena Withdraws as Nadal Hits Next Round (2020, October 1). ThisDay Newspaper. Retrieved from: https://www.thisdaylive.com/index.php/2020/10/01/french-open-serenawithdraws-as-nadal-hits-next-round/

Fu, M. C., Ellenbecker, T. S., Renstrom, P. A., Windler, G. S., \& Dines, D. M. (2018). Epidemiology of injuries in tennis players. Current Reviews in Musculoskeletal Medicine, 11(1), 1-5. doi:10.1007/ s12178-018-9452-9

Gescheit, D. T., Cormack, S. J., Duffield, R., Kovalchik, S., Wood, T. O., Omizzolo, M., \& Reid, M. (2017). Injury epidemiology of tennis players at the 2011-2016 Australian Open Grand Slam. British Journal of Sports Medicine, 51(17), 1289-1294. doi:10.1136/bjsports-2016-097283

Ghaffar, A., Hyder, A. A., \& Bishai, D. (2001). Newspaper reports as a source for injury data in developing countries. Health Policy and Planning, 16(3), 322-325. doi: 10.1093/heapol/16.3.322

Hassan, I., \& Azmi, M. M. L. (2018). Readers' preferences for print and online newspapers in Northwestern Nigeria. International Journal of Academic Research in Business and Social Sciences, 8(6), 965- 974. doi: 10.6007/IJARBSS/v8-i6/4294

Hassan, I., Musa, R. M., Azmi, M. N. L., Abdullah, M. R., \& Abdullah, A. T. H. (2020). News reporting of injury prevalence in football: A study of selected Nigerian online newspapers. Media Watch, 11(2), 323-336. doi:10.15655/mw/2020/v11i2/195652

Hjelm, N., Werner, S., \& Renstrom, P. (2010). Injury profile in junior tennis players: A prospective twoyear study. Knee Surgery, Sports Traumatology, Arthroscopy, 18(6), 845-850. doi 10.1007/ s00167-010-1094-4

Hsieh, H. F., \& Shannon, S. E. (2005). Three approaches to qualitative content analysis. Qualitative Health Research, 15(9), 1277-1288. doi: 10.1177/1049732305276687

Injury-troubled Osaka heads to French Open after hectic clay season (2019, May 21). Vanguard Newspaper. Retrieved from: https://www.vanguardngr.com/2019/05/breaking-communityshuts-down-chevrons-otunana-flow-station/

International Tennis Federation (2021). The World Cup of Tennis. Retrieved from: https://www.daviscup.com/en/organisation/about-the-itf.aspx

Kaiser, P., Stock, K., Benedikt, S., Ellenbecker, T., Kastenberger, T., Schmidle, G., \& Arora, R. (2021). Acute Tennis Injuries in the Recreational Tennis Player. Orthopaedic Journal of Sports Medicine, 9(1), 132-146. doi:10.1177/2325967120973672

Kim, K., \& McCombs, M. (2007). News story descriptions and the public's opinions of political candidates. Journalism and Mass Communication Quarterly, 84(2), 299-314. doi: 10.1177/ 107769900708400207

Kovacs, M. S. (2006). Applied physiology of tennis performance. British Journal of Sports Medicine, 40(5), 381-386. doi:10.1136/bjsm.2005.023309 
Kovacs, M. S., Ellenbecker, T. S., Kibler, W. B., Roetert, E. P., \& Lubbers, P. (2014). Injury trends in American competitive junior tennis players. Journal of Medicine and Science in Tennis, 19(1), 19-24.

Kühne, C. A., Zettl, R. P., \& Nast-Kolb, D. (2004). Injuries-and frequency of complaints in competitive tennis-and leisure sports. Sportverletzung Sportschaden: Organ der Gesellschaft fur Orthopadisch-Traumatologische Sportmedizin, 18(2), 85-89. doi:10.1055/s-2004-813049

Lim, J. (2010). Convergence of attention and prominence dimensions of salience among major online newspapers. Journal of Computer-Mediated Communication, 15 (2): 293- 313. doi:10.1111/ j.1083-6101.2010.01521.x

Lynall, R. C., Kerr, Z. Y., Djoko, A., Pluim, B. M., Hainline, B., \& Dompier, T. P. (2015). Epidemiology of National Collegiate Athletic Association men's and women's tennis injuries, 2009/20102014/2015. British Journal of Sports Medicine, 50(19), 1211-1216. doi:10.1136/bjsports-2015095360

Maquirriain, J., \& Baglione, R. (2016). Epidemiology of tennis injuries: an eight-year review of Davis Cup retirements. European Journal of Sport Science, 16(2), 266-270. doi:10.1080/17461391.2015.1009493

McCombs, M. E., \& Shaw, D. L. (1993). The evolution of agenda-setting research: Twenty-five years in the marketplace of ideas. Journal of Communication, 43(2), 58-67.

McCombs, M., \& Shaw, D. (1972). The agenda-setting function of mass media. Public Opinion Quarterly, 36 (2): 176-187. doi: 10.1086/267990

McCurdie, I., Smith, S., Bell, P. H., \& Batt, M. E. (2017). Tennis injury data from The Championships, Wimbledon, from 2003 to 2012. British Journal of Sports Medicine, 51(7), 607-611. doi:10.1136/ bjsports-2015-095552

Musa, R. M., Hassan, I. Abdullah, M. R., Azmi, M. N. L., \& Mat-Rasid, S. M. (2020). Injury Prevalence, Types and Mechanisms in Football: A Media-based Approach. Asian Journal of Pharmaceutical Research and Health Care. doi:10.18311/ajprhc/2019/24915

Okwuchukwu, O. G. (2014). The influence of media ownership and control on media agenda-setting in Nigeria. International Journal of Humanities Social Sciences and Education, 7 (1): 36-45

Oleinik, A. (2011). Mixing quantitative and qualitative content analysis: Triangulation at work. Quality \& Quantity, 45(4), 859-873. doi: 10.1007/s11135-010-9399-4

Pluim B.M., Windler G. (2018) Epidemiology of Tennis Injuries. In Di Giacomo G., Ellenbecker T., Kibler W. (eds). Tennis Medicine. Springer, Cham. doi:10.1007/978-3-319-71498-1_3

Pluim BM, Safran M. (2004). From breakpoint to advantage. Includes description, treatment, and prevention of all tennis injuries. Vista: USRSA.

Pluim, B. M., Fuller, C. W., Batt, M. E., Chase, L., Hainline, B., Miller, S., ... \& Wood, T. O. (2009). Consensus statement on epidemiological studies of medical conditions in tennis, April 2009. British Journal of Sports Medicine, 43(12), 893-897. doi: 10.1136/bjsm.2009.064915

Pluim, B. M., Groppel, J. L., Miley, D., Crespo, M., \& Turner, M. S. (2018). Health benefits of tennis. British Journal of Sports Medicine, 52(3), 201-202. doi: 10.1136/bjsports-2017-098623

Pluim, B. M., Loeffen, F. G. J., Clarsen, B., Bahr, R., \& Verhagen, E. A. L. M. (2016). A one-season prospective study of injuries and illness in elite junior tennis. Scandinavian Journal of Medicine and Science in Sports, 26(5), 564-571. doi: 10.1111/sms.12471

Pluim, B. M., Staal, J. B., Marks, B. L., Miller, S., \& Miley, D. (2007). Health benefits of tennis. British Journal of Sports Medicine, 41(11), 760-768. doi:10.1136/bjsm.2006.034967 
Pluim, B. M., Staal, J. B., Windler, G. E., \& Jayanthi, N. (2006). Tennis injuries: occurrence, aetiology, and prevention. British Journal of Sports Medicine, 40(5), 415-423. doi: 10.1136/bjsm.2005.023184

Potter, J. W. (2012). Media effects. California: Sage Publications.

Sell, K., Hainline, B., Yorio, M., \& Kovacs, M. (2014). Injury trend analysis from the US Open Tennis Championships between 1994 and 2009. British Journal of Sports Medicine, 48(7), 546-551. doi:10.1136/bjsports-2012-091175

Top Ten Nigerian Newspapers (2019). Retrieved from http: https://answersafrica.com/top10-nigerian-newspapers-most-read-online.html

Verhagen, E., Clarsen, B., Capel-Davies, J., Collins, C., Derman, W., de Winter, D., ... \& Pluim, B. M. (2021). Tennis-specific extension of the International Olympic Committee consensus statement: methods for recording and reporting of epidemiological data on injury and illness in sport 2020. British Journal of Sports Medicine, 55(1), 9-13. doi:10.1136/bjsports-2020-102360

Weaver, D. H. (2007). Thoughts on agenda setting, framing, and priming. Journal of Communication, 57 (1): 142-147. doi:10.1111/j.1460-2466.2006.00333.x

Wu, H. D., \& Coleman, R. (2009). Advancing agenda-setting theory: The comparative strength and new contingent conditions of the two levels of agenda-setting effects. Journalism \& Mass Communication Quarterly, 86(4), 775-789. doi: 10.1177/107769900908600404 